\title{
Effects of Soil-Applied Late Blight Foliar Fungicides on Infection of Potato Tubers by Phytophthora infestans
}

\author{
L. D. Porter, USDA-ARS, Vegetable and Forage Crops Research Unit, Prosser, WA 99350; and T. F. Cummings and \\ D. A. Johnson, Department of Plant Pathology, Washington State University, Pullman 99164-6430
}

\begin{abstract}
Porter, L. D., Cummings, T. F., and Johnson, D. A. 2006. Effects of soil-applied late blight foliar fungicides on infection of potato tubers by Phytophthora infestans. Plant Dis. 90:964-968.

Potato tuber infection was assessed under greenhouse and outdoor conditions when late blight foliar fungicides were applied to soil $24 \mathrm{~h}$ prior to soil infestation with a suspension of zoospores and sporangia of Phytophthora infestans. Spore viability of P. infestans in soil treated with various fungicides was determined using buried healthy whole tubers and by assaying infested soil applied to freshly cut tuber disks. Protection of tubers and tuber disks from infection was more effective when soil was treated with mancozeb, metiram, and cyazofamid than with other fungicides. Whole tuber infections were significantly less in soils treated with mancozeb, metiram, fluazinam, and fenamidone than when treated with distilled water. Infection of buried tubers and tuber disks was prevented for 3 to 5 days following a single soil application of mancozeb or metiram under outdoor conditions. The tuber disk method was more sensitive in determining the efficacy of a fungicide in inhibiting infection and spore viability than using whole buried tubers. However, both methods of determining viability may determine different modes of action of some fungicides that inhibit infection since whole tubers were not infected when protected by some fungicides but tuber disks were infected.
\end{abstract}

Late blight, caused by Phytophthora infestans, can severely reduce potato yields in the field and cause losses during storage. Yield losses in the field occur when tubers become infected during the growing season. Storage losses result from tuber infection either in the field or at harvest. The storage losses from late blight tuber rot were estimated to be $\$ 3.0$ million in 1995 and \$1.4 million in 1998 in the Columbia Basin of Washington and Oregon $(13,14)$. Tubers become infected in the field when zoospores or sporangia of $P$. infestans are washed from the surface of infected foliage and then come in contact with tubers. Tuber infection occurs through buds, lenticels, and wounds. Tubers can become infected at low levels of inoculum (18), and as few as 2 sporangia/ml of water has been shown to initiate tuber infections (7). Initial lesion expansion is usually most apparent just under the skin of the tuber where the starchy tissue appears rust-red to dark brown. Infection by $P$. infestans generally leads to secondary invasion by bacterial soft rot and dry rot pathogens (8), resulting in greater storage losses.

Corresponding author: Lyndon D. Porter

E-mail: lporter@pars.ars.usda.gov

Accepted for publication 17 March 2006.

DOI: 10.1094/PD-90-0964

This article is in the public domain and not copyrightable. It may be freely reprinted with customary crediting of the source. The American Phytopathological Society, 2006.
Reducing the risk of tuber rot due to $P$. infestans is an annual concern for potato growers in the Columbia Basin, WA. Current recommended management practices to reduce tuber infection include: (i) using adequate planting depths and hilling practices to reduce the likelihood of tuber contact with spores by way of soil cracks or shallow soil, (ii) using proper irrigation management, (iii) continuing timely fungicide applications until harvest, and (iv) avoiding harvesting tubers during wet weather. Foliar desiccation prior to harvest did not significantly impact tuber rot due to P. infestans in the Columbia Basin (15); therefore it is not part of the recommended management practices.

There is limited information on the effects of current foliar fungicides on the viability of $P$. infestans sporangia and zoospores in soil (3-5). Also, there is no information available on their efficacy and duration of activity on the soil surface, and whether they can prevent or reduce tuber infection. Understanding the effects of fungicide activity would assist growers in managing tuber rot. The objectives of the study were to evaluate the efficacy and duration of activity of selected foliar fungicides applied to the soil surface in reducing infection of potato tubers by $P$. infestans.

\section{MATERIALS AND METHODS}

Soil preparation. Quincy medium sand (19) with a $\mathrm{pH}$ of 6.6 to 7.3 was used for all experiments. The sand was removed from native rangeland (sagebrush scrub) that had never been cropped with potatoes. Soil was air-dried and sifted through a 0.5 $\mathrm{cm}^{2}$ mesh screen in order to remove rocks and debris. Pots $35 \mathrm{~cm}$ in diameter by 25 $\mathrm{cm}$ in depth were filled with gravel to a depth of $5 \mathrm{~cm}$. The mean diameter of the gravel measured $0.63 \mathrm{~cm}$. Sand was placed on top of the gravel to a depth of $19 \mathrm{~cm}$.

Tuber placement in pots. Certified healthy whole seed tubers of cultivar Ranger Russet were used as a bioassay to assess infectivity of inoculum, and were maintained at $4^{\circ} \mathrm{C}$ until use. Tubers used in experiments were uniform in size or were uniform in size within replicates. (See individual experiments for tuber sizes.) Tubers were buried in pots at a depth of 1 to $2 \mathrm{~cm}$. Tubers were buried so the stolon and bud end of a tuber were at the same soil depth, and one tuber was not directly above or adjacent to another. The tubers at each depth were spaced equidistantly apart. Tuber depth was measured from the uppermost part of the tuber to the soil surface. Tubers were placed at least $2.5 \mathrm{~cm}$ from the edge of the pot.

Soil water potential and air temperature. Watermark water potential sensors (Spectrum Technologies Inc., Plainsfield, IL) were buried just beneath the soil surface and extended $5 \mathrm{~cm}$ into the potted soil. Sensors were placed either in the center of each pot or $5 \mathrm{~cm}$ from the side. Water potential was determined 10 to 15 min after irrigation water was applied to pots and again $24 \mathrm{~h}$ postirrigation. The mean and range of water potential for treatments were calculated from replicate values. Atmospheric temperature was recorded every 15 to 30 min using a model 450 Watch Dog Data Logger (Spectrum Technologies). Mean air temperature during application of inoculum for greenhouse experiments was $18.5 \pm 4^{\circ} \mathrm{C}$. Air temperatures for outdoor experiments ranged from 12 to $28^{\circ} \mathrm{C}$, and mean water potentials for greenhouse and outdoor experiments ranged from -8 to -13 centibars during the first $24 \mathrm{~h}$ postapplication of inoculum. Water potential values between 0 and -10 centibars represented saturated soil.

Water application. Adjustable water drippers model B02 (Dig Corporation, San Marcos, CA) were held in place with stakes over the center of each pot. Stakes holding the drippers were tilted toward the edge of the pots and away from the buried tubers at a $45^{\circ}$ angle. Drippers were approximately 2.0 to $2.5 \mathrm{~cm}$ above the soil 
surface. Water was emitted at a rate of 14 $\mathrm{ml} / \mathrm{s}$ in a circular pattern approximately 23 to $24 \mathrm{~cm}$ in diameter. Soil in each pot was prewetted with approximately $70 \mathrm{ml}$ of water before the soil was infested with a spore suspension.

Application of fungicides to soil. Fungicides were applied to the soil surface using individual 710-ml Impact sprayer bottles (Unisan, Chattanooga, TN) in four experiments. Each sprayer bottle was calibrated to apply a rate of 281 liters water/ha (except in experiment B, where 318 liters water/ha were applied) to the soil surface in each pot for each fungicide application. Application rates of foliar fungicides to the soil were based on the recommended label rates for foliar management of late blight. Plastic bags were used to cover nontargeted pots during application to avoid fungicide contamination among treatments.

Sporangia production. A US-8 clonal lineage (9) of $P$. infestans was used in these studies. The isolate was collected from central Washington in 2002 and was maintained and increased on excised leaflets of cv. Ranger Russet or Russet Burbank. Sporangia from lesions on leaflets were rinsed with distilled water into a beaker to a concentration of 5 to $6.5 \times 10^{4}$ sporangia/ml. The spore suspension was incubated for $2 \mathrm{~h}$ at $4^{\circ} \mathrm{C}$ to induce zoospore formation. A $1 \mathrm{~cm}^{2}$ Whatman no. 2 filter paper was then immersed for approximately $1 \mathrm{~s}$ in the suspension and placed in the center of the adaxial surface of a freshly cut leaflet. Approximately 100 to 125 inoculated leaflets for each experiment were placed with the adaxial surface downward on a fiberglass screen over moistened paper towels in plastic containers. Leaflets were incubated at $15^{\circ} \mathrm{C}$ for 6 days with an 18 -h photoperiod. Sporangia that formed were rinsed from leaflets with distilled water into a 4-liter flask, and the concentration of sporangia was determined using a hemacytometer and adjusted to $10^{4}$ sporangia/ml water. The sporangia suspension was then chilled for $2 \mathrm{~h}$ at $4^{\circ} \mathrm{C}$ to induce zoospore formation. A 50- $\mu$ d drop of the spore suspension was observed after the chill period under a compound microscope to confirm zoospore formation.

Application of inoculum to soil. A spore suspension containing $100 \mathrm{ml}$ of sporangia and zoospores of $P$. infestans was applied to each pot using a graduated cylinder. The inoculum formed an approximate 5 -cm-wide band on the soil surface over buried tubers. Application of inoculum was completed for each experiment within 25 to $30 \mathrm{~min}$. Inoculum was applied to the soil at night when cooler temperatures prevailed, to maximize survival, activity, and infection by spores $(2,25,28)$.

Tuber disk bioassay. Tuber disks used to assay viability of spores were cut from certified seed tubers of cv. Ranger Russet.
Tubers were washed thoroughly in running tap water, rinsed with distilled water, immersed in $96 \%$ ethanol, and then disinfested using a propane burner. Tuber disks were aseptically cut to a thickness of 0.5 $\mathrm{cm}$ with a 4- to $5-\mathrm{cm}$ diameter using a knife. The knife was sterilized between each cut using a propane burner. Tuber disks were then placed on a fiberglass screen over moistened Whatman no. 2 filter paper in $9-\mathrm{cm}$-diameter by $1.5-\mathrm{cm}$ deep petri dishes.

Viability of zoospores and sporangia in the soil was determined $24 \mathrm{~h}$ following application of inoculum. Two soil samples per pot were taken after the second application of water by dividing the soil surface in a pot in half and selecting a location within each half where spores had been applied. A soil bore was used to take a 1$\mathrm{cm}$-diameter by $1-\mathrm{cm}$-deep soil plug. The soil from each plug was placed on a freshly cut potato disk. One milliliter of sterile distilled water was applied on top of the soil to spread the soil evenly on the tuber disk surface. Tuber disks in petri dishes were randomly arranged in an 18.5liter plastic container with wetted paper towels in the bottom and incubated for 10 days at $15^{\circ} \mathrm{C}$ with an 18 -h photoperiod. The presence or absence of sporulation by $P$. infestans was then observed by microscopic observation.

Assessment of whole tuber infection. Tubers were harvested and assessed for rot 14 days after application of inoculum. Tubers were examined for symptoms of late blight by cutting the tubers perpendicular to the bud and stolon ends of each tuber at approximately $0.5-\mathrm{cm}$ intervals. Tuber disks were removed from tubers with disease symptoms and placed on fiberglass screens over moistened filter paper in 9 -cm-diameter by 1.5 -cm-deep petri dishes. Petri dishes were randomly arranged in an 18.5-liter plastic container with moistened paper towels in the bottom and incubated at $15^{\circ} \mathrm{C}$ with an 18 -h photoperiod for 24 to $48 \mathrm{~h}$. Tuber disks were then observed for sporulation of $P$. infestans.

Effects of fungicides on spore mortality and tuber infection. Spore mortality and tuber infection were assessed when fungicides were applied to the soil surface in four experiments labeled A to D. Each experiment was repeated. The effects of six individual fungicides, one fungicide combination, and a nontreated distilled water control were evaluated in greenhouse trials in experiment A. The soil surface was treated with one of the eight following treatments (See Table 1 for rates): 1, distilled water; 2, copper hydroxide (Kocide, Griffin LLC,Valdosta, GA); 3, chlorothalonil (Bravo WS, Syngenta Crop Protection, Inc., Greensboro, NC); 4, triphenyltin hydroxide (Super Tin $80 \mathrm{WP}$, Griffin LLC); 5, cymoxanil (Curzate 60DF, E. I. du Pont de Nemour and Co., Crop
Protection, Wilmington, DE); 6, metiram (Polyram 80 DF, Loveland Products, Inc., Greeley, CO); 7, mancozeb (Penncozeb 75 DF, Cerexagri, Inc., King of Prussia, PA); and 8 , metiram + triphenyltin hydroxide. Treatments were arranged in a completely randomized design with three replicates for a total of 24 pots. Soil in an additional pot with six tubers exposed at the surface was sprayed with distilled water and used as an additional positive control to ensure inoculum was infectious (25th pot). Each pot contained six tubers. Tubers weighed 184 to $227 \mathrm{~g}$ in the first trial and 125 to $563 \mathrm{~g}$ in the second trial.

The fungicides and water control were applied to the surface of the soil and allowed to dry for $24 \mathrm{~h}$. Soil in each pot was then infested with approximately $10^{6}$ sporangia in $100 \mathrm{ml}$ of water using a concentration of $10^{4}$ sporangia/ml water. Approximately $800 \mathrm{ml}$ water was added to each pot after application of inoculum, and again $24 \mathrm{~h}$ later. This amount of water is equivalent to $0.83 \mathrm{~cm}$ of water; potato fields in the Columbia Basin are often watered with 0.625 to $0.833 \mathrm{~cm}(1 / 4$ to $1 / 3$ in) of water during one revolution of a center-pivot irrigation system.

In experiment $\mathrm{B}$, the soil surface was treated with one of the 11 following treatments (See Table 1 for rates): 1, distilled water; 2, fluazinam (Omega 500F, Syngenta Crop Protection); 3, dimethomorph (Acrobat MZ, BASF Corp., Research Triangle Park, NC); 4, boscalid (Endura, BASF Corp.); 5, phosphorous acid and mono- and di-potassium salts (Phostrol, Nufarm, Sugar Land, TX); 6, azoxystrobin (Quadris, Syngenta Crop Protection); 7, fenamidone (Reason, Bayer CropScience, Research Triangle Park, NC); 8, pyraclostrobin (Headline, BASF Corp.); 9, cyazofamid (Ranman 400 SC, ISK Biosciences Corp., Concord, OH); 10, mancozeb; and 11, zoxamide + mancozeb (Gavel $75 \mathrm{DF}$, Dow AgroSciences, Indianapolis, IN). Arrangement of treatments, number of replications, positive controls, and number of tubers per pot were the same as previously described for experiment A.

Experiment $\mathrm{C}$ was conducted outdoors near the Washington State University Campus, Pullman. Pots were buried to the upper rim in sandy soil and filled with Quincy medium sand. Pots were organized in six rows and five columns. One row had only two pots; all other rows had five for a total of 27 pots. Two factors, soil fungicide treatment and time interval until soil infestation after application of the fungicide to the soil, were arranged in a 3 by 3 factorial design for a total of 9 treatments with three replicates per treatment. Soil treatments included mancozeb, metiram, and distilled water, and the time intervals of postfungicide application of inoculum to the soil were $24 \mathrm{~h}, 72 \mathrm{~h}$, and 7 days. Six tubers weighing 100 to $286 \mathrm{~g}$ were buried to a depth of $1 \mathrm{~cm}$ in each pot. Approximately 
$800 \mathrm{ml}$ of water was added to each pot immediately after application of inoculum. The pots were watered with $800 \mathrm{ml}$ every $48 \mathrm{~h}$ following initial irrigation until the last application of inoculum at day seven.

Survival of zoospores and sporangia in soil was assayed $24 \mathrm{~h}$ after application of inoculum by placing soil plugs on tuber disks as previously described. Incidence of tuber disks with sporulation was recorded following 6 days of incubation. Tuber disks with no sporulation after 6 days were again observed after 12 days of incubation for sporulation. Buried tubers were removed from the pots 2 weeks after application of inoculum and assessed for infection.

In experiment $\mathrm{D}$, mancozeb was tested for duration of protection to tubers under outdoor conditions at 3,4,5,6, and 7 days after being applied to the soil surface. Approximately $800 \mathrm{ml}$ of water was added to each pot immediately after application of inoculum. The pots were watered with 800 $\mathrm{ml}$ every $48 \mathrm{~h}$ following the initial irrigation until the last application of inoculum at day seven. Soil plugs were removed from the soil surface at each time interval as previously described. There were four replicates per treatment, and treatments were arranged in a completely randomized design.

Statistics. The response data for tuber infection were binary: infection or no infection. Therefore, data for incidence of tuber infection were analyzed using techniques applicable to binary data: logistic

Table 1. Incidence of infected whole tubers buried in soil and incidence of sporulation on tuber disks when the soil surface was treated with fungicide or water and then infested with spores of Phytophthora infestans (experiments A and $\mathrm{B})^{\mathrm{p}}$

\begin{tabular}{|c|c|c|c|c|c|}
\hline \multirow[b]{2}{*}{ Treatment } & \multirow[b]{2}{*}{ a.i./has } & \multicolumn{2}{|c|}{$\begin{array}{l}\text { Mean } \% \text { incidence of } \\
\text { infected whole tubers }\end{array}$} & \multicolumn{2}{|c|}{$\begin{array}{c}\text { Mean \% incidence of } \\
\text { sporulation on tuber disks }\end{array}$} \\
\hline & & Trial 1 & Trial 2 & Trial 1 & Trial 2 \\
\hline \multicolumn{6}{|l|}{ Experiment A } \\
\hline Water (surface) ${ }^{t}$ & 281 liter & $100 \mathrm{a}^{\mathrm{u}}$ & $100 \mathrm{a}$ & $100 \mathrm{a}$ & $\ldots{ }^{v}$ \\
\hline Water $(1 \mathrm{~cm})^{\mathrm{w}}$ & 281 liter & $89 a b$ & $26 \mathrm{~b}$ & $100 \mathrm{a}$ & $80 \mathrm{a}$ \\
\hline Copper hydroxide & $8.85 \mathrm{~kg}$ & $72 \mathrm{ab}$ & $17 \mathrm{bc}$ & $100 \mathrm{a}$ & $33 \mathrm{~b}$ \\
\hline Chlorothalonil & $1.26 \mathrm{~kg}$ & $72 \mathrm{ab}$ & $17 \mathrm{bc}$ & $83 \mathrm{a}$ & $33 \mathrm{~b}$ \\
\hline Triphenyltin hydroxide & $111.6 \mathrm{~g}$ & $56 \mathrm{bc}$ & $17 \mathrm{bc}$ & $83 \mathrm{a}$ & $67 \mathrm{a}$ \\
\hline Cymoxanil & $134.5 \mathrm{~g}$ & $44 \mathrm{c}$ & $11 \mathrm{bc}$ & $50 \mathrm{~b}$ & $33 \mathrm{~b}$ \\
\hline Metiram + & $1.792 \mathrm{~g}$ & & & & \\
\hline triphenyltin hydroxide & $111.6 \mathrm{~g}$ & $6 \mathrm{~d}$ & $6 \mathrm{c}$ & $0 \mathrm{c}$ & $17 \mathrm{~b}$ \\
\hline Metiram & $1.79 \mathrm{~kg}$ & $0 \mathrm{~d}$ & $0 \mathrm{c}$ & $0 \mathrm{c}$ & $0 \mathrm{~b}$ \\
\hline Mancozeb & $1.68 \mathrm{~kg}$ & $0 \mathrm{~d}$ & $0 \mathrm{c}$ & $0 \mathrm{c}$ & $0 \mathrm{~b}$ \\
\hline LSD $^{x}$ & $\mathrm{NA}^{\mathrm{y}}$ & 23 & 18 & 31 & 48 \\
\hline \multicolumn{6}{|l|}{ Experiment B } \\
\hline Water $(1 \mathrm{~cm})$ & 318 liter & $5 \mathrm{ab}$ & $7 \mathrm{a}$ & $80 \mathrm{ab}$ & $75 \mathrm{ab}$ \\
\hline Fluazinam & $280 \mathrm{~g}$ & $0 \mathrm{~d}$ & $1 \mathrm{c}$ & $83 \mathrm{a}$ & $68 a b c$ \\
\hline Dimethomorph & $112 \mathrm{~g}$ & $3 \mathrm{bc}$ & $0 \mathrm{c}$ & $82 \mathrm{ab}$ & $50 \mathrm{bc}$ \\
\hline Boscalid & $122.5 \mathrm{~g}$ & $7 \mathrm{a}$ & $\ldots$ & $82 \mathrm{ab}$ & \\
\hline Phosphorous acid & $7.49 \mathrm{~kg}$ & $3 \mathrm{bc}$ & $4 a b c$ & $80 \mathrm{ab}$ & $63 a b c$ \\
\hline Azoxystrobin & $224 \mathrm{~g}$ & $4 \mathrm{bc}$ & $3 \mathrm{bc}$ & $80 \mathrm{ab}$ & $55 \mathrm{bc}$ \\
\hline Fenamidone & $299.5 \mathrm{~g}$ & $0 \mathrm{~d}$ & $3 \mathrm{bc}$ & $80 \mathrm{ab}$ & $58 \mathrm{abc}$ \\
\hline Pyraclostrobin & $224 \mathrm{~g}$ & $2 \mathrm{~cd}$ & $5 \mathrm{ab}$ & $72 \mathrm{~b}$ & $47 \mathrm{c}$ \\
\hline Cyazofamid & $78.8 \mathrm{~g}$ & $3 \mathrm{bcd}$ & $0 \mathrm{c}$ & $3 \mathrm{c}$ & $7 \mathrm{~d}$ \\
\hline Mancozeb & $1.68 \mathrm{~kg}$ & $0 \mathrm{~d}$ & $0 \mathrm{c}$ & $1 \mathrm{c}$ & $0 \mathrm{~d}$ \\
\hline Zoxamide $^{z}$ & $224 \mathrm{~g}$ & $0 \mathrm{~d}$ & $1 \mathrm{c}$ & $0 \mathrm{c}$ & $2 \mathrm{~d}$ \\
\hline LSD & NA & 3 & 5 & 12 & 27 \\
\hline
\end{tabular}

${ }_{\mathrm{p}}$ Fungicides and water controls were arranged in a completely randomized design with three replicates. Each pot contained six whole cv. Ranger Russet tubers buried 1 to $2 \mathrm{~cm}$ in a Quincy medium sand in pots in a greenhouse. Soil was infested with $10^{6}$ sporangia/pot in $100 \mathrm{ml}$ of water that had been chilled for $2 \mathrm{~h}$ at $4^{\circ} \mathrm{C}$ to induce zoospore formation. Water was applied at $800 \mathrm{ml}$ to the soil in each pot after application of inoculum and again $24 \mathrm{~h}$ later. Tuber disks were inoculated with infested soil $24 \mathrm{~h}$ after soil infestation and $48 \mathrm{~h}$ after application of fungicides or water to the soil. Active ingredients and brand names tested were: copper hydroxide $=$ Kocide, chlorothalonil $=$ Bravo WS, triphenyltin hydroxide $=$ Super Tin $80 \mathrm{WP}$, cymoxanil $=$ Curzate $60 \mathrm{DF}$, metiram $=$ Polyram $80 \mathrm{DF}$, mancozeb $=$ Penncozeb $75 \mathrm{DF}$, fluazinam $=$ Omega 500F, dimethomorph $=$ Acrobat MZ, boscalid $=$ Endura, phosphorous acid $=$ Phostrol, azoxystrobin $=$ Quadris, fenamidone $=$ Reason, pyraclostrobin $=$ Headline, cyazofamid $=$ Ranman 400, zoxamide $=$ Gavel 75 DF.

${ }^{\mathrm{q}}$ Whole tubers assayed for infection 14 days after application of inoculum to soil.

${ }^{\mathrm{r}}$ Two $1 \mathrm{~cm}^{3}$ soil plugs per pot were placed on separate tuber disks of cv. Ranger Russet and incubated at $15^{\circ} \mathrm{C}$ for 6 days.

${ }^{\mathrm{s}}$ Active ingredient of fungicide or water per hectare.

${ }^{t}$ Soil surface treated with water and partially exposed tubers buried level with the soil surface.

${ }^{\text {u }}$ Different letters represent significant difference between the treatments determined using a series of pair-wise differences by tests of two proportions with an adjusted Bonferroni procedure $(P<0.05)$.

${ }^{v}$ Missing data.

${ }^{\mathrm{w}}$ Soil surface treated with water and tubers buried $1 \mathrm{~cm}$ below the soil surface.

${ }^{x}$ Least significant difference among treatments.

${ }^{\mathrm{y}} \mathrm{NA}=$ not applicable.

${ }^{z}$ Gavel $75 \mathrm{DF}$ contains mancozeb at the rate of $1.68 \mathrm{~kg}$ a.i./ha in addition to zoxamide. regression $(11,24)$, test of pair-wise differences of two proportions with a multiplicity adjusted Bonferroni procedure (16), and Goodness of Fit tests (11). Analysis was performed using MINITAB Release 12.1 (Minitab Inc., University Park, PA) and SAS (SAS Institute, Cary, NC). Data from all experiments were separated or quasi-separated (24). Initially for these experiments a chi-square test of association was done to look for associations between the responses and the explanatory variables and followed by a test of pairwise differences of two proportions with a Bonferroni adjustment. The results of the preliminary chi-square tests are not reported as they are similar to the results obtained through the test of proportions.

\section{RESULTS}

Effects of fungicides on spore mortality and tuber infection. In experiment $A$, whole tubers did not become infected and sporulation of $P$. infestans did not occur on tuber disks assayed with soil treated with either metiram or mancozeb in both trials (Table 1). Incidence of whole tuber infection did not vary significantly $(P \geq 0.05)$ in both trials when soil was treated with copper hydroxide, chlorothalonil, triphenyltin hydroxide, or water (Table 1). Incidence of sporulation on tuber disks was significantly less $(P \leq 0.05)$ when soil was treated with metiram + triphenyltin hydroxide than with water, copper hydroxide, chlorothalonil, triphenyltin hydroxide, and cymoxanil in the first but not in the second trial (Table 1). Infection of tubers and sporulation on tuber disks were intermediate for cymoxanil (Table 1). Tuber infection was substantially less for all treatments in the second trial than in the first trial, and whole tuber infection did not significantly differ among the fungicide treatments in the second trial.

In experiment $\mathrm{B}$, infection of whole tubers was significantly less $(P<0.001)$ when soil was treated with fluazinam, fenamidone, mancozeb, and mancozeb + zoxamide than with distilled water in both trials (Table 1). Incidence of tuber disks with sporulation was significantly less $(P<0.001)$ when assayed soil was treated with cyazofamid, mancozeb, and zoxamide + mancozeb than with distilled water (Table 1).

In experiment $\mathrm{C}$, tubers did not become infected when soil treated with mancozeb was later infested with $P$. infestans either 1 or 3 days after fungicide application; whereas tubers from the nontreated control were infected (Table 2). Sporulation did not occur when soil cores were assayed on tuber disks from soil that was infested with $P$. infestans either 1 or 3 days after treatment of soil with either mancozeb or metiram (Table 2). Tuber infection also did not occur in soil treated with metiram when soil was infested 1 day after application of the fungicide. Limited tuber infection $(17 \%)$ occurred when soil was infested 3 
days after application of metiram. Sporulation on tuber disks assayed with infested soil did not occur for soil treated with mancozeb or metiram when soil was infested 1 or 3 days postfungicide application (Table 2). Incidence of whole tuber infection and incidence of sporulation on tuber disks were not significantly different from the distilled water treatments when soil treated with mancozeb and metiram were infested 7 days after fungicide application $(P>0.05$, Table 2$)$. Tuber disks that did not produce sporangia of $P$. infestans after 6 days of incubation also did not sporulate after 12 days of incubation.

In experiment $\mathrm{D}$, infection and sporulation did not occur in both trials when infested soil cores were assayed on tuber disks from soil that was infested with $P$. infestans 5 days after treatment of soil with mancozeb (Table 3). Incidence of infection and sporulation was also significantly less in both trials for soil treated with mancozeb than for soil treated with water when infested soil cores were assayed on tuber disks from soil that was infested with $P$. infestans 7 days after treatment of soil with mancozeb or water $(P>0.05$, Table 3$)$.

\section{DISCUSSION}

Several fungicides are used to prevent infection of potato foliage by $P$. infestans in the Columbia Basin. However, infections may still result from poor fungicide timing and application techniques, fungicide resistance, and when late blight inoculum overwhelms the foliar protectant fungicide. Concern for protecting subterranean tubers increases when foliar infections occur because spores produced on the canopy are washed from the foliar surface to the soil where tuber infection may result. The question may be asked, "Is there a certain foliar fungicide that is better than others in protecting belowground tubers from infection once foliar infection has occurred?" The presence of an effective protective fungicide at the soil surface would be beneficial because sporangia of $P$. infestans, as demonstrated in previous studies, did not readily wash through soil, and less than $1 \%$ of sporangia were found deeper than $5 \mathrm{~cm}$ in sandy soil $(12,21,22)$. As a result, it appears that the majority of spores exist near the soil surface and the application of an effective fungicide to the soil would be beneficial in either killing or inactivating spores before they are washed into the soil or through soil cracks and cavities during irrigation and rainfall or by other mechanisms.

There are many reasons why fungicides that are efficacious against foliar infections caused by $P$. infestans may not be effective in preventing tuber infection when applied to the soil. These include: (i) soil microbial populations may be more effective than phyllosphere organisms in breaking down and reducing the effective half-life of the fungicide; (ii) the foliar fungicide may activate natural defense mechanisms within the plant, making it more effective as a foliar application; (iii) fungicide soil mobilities are different, and a highly mobile fungicide may be leached quickly from the soil surface or easily diluted to concentrations that are not effective; and (iv) soil-applied fungicides may form complexes with the soil chemistry rendering them less or completely ineffective. The "ideal" fungicide to prevent tuber infection would: (i) kill or inactivate the pathogen before tuber infection; (ii) remain on the soil surface as a soil barrier to tuber infection; and (iii) have a relatively long half-life to provide protection for 7 to 10 days.

Mancozeb and metiram, both ethylene bisdithiocarbamates (EBDCs), protected tubers from infection, and both were fungicidal to spores of $P$. infestans on soil in this study. However, tuber protection pro-

vided by the EBDC fungicides was shortlived, and application of these fungicides would have to be made at 5-day intervals to maintain adequate tuber protection. Mancozeb and metiram, applied to soil at key times when the soil is exposed to chemical deposition such as late in the growing season when the crop canopy begins to open and after chemical defoliation or defoliation due to late blight, may provide protection against the washing of zoospores and sporangia through soil and subsequent tuber infection.

EBDC fungicides cannot be applied within 14 days of harvest in the state of Washington because of label restriction; however, there are 12 states where mancozeb (Penncozeb 75 DF) can be applied up to 3 days before harvest (see label), making it possible to maintain tuber protection until harvest in these states if the

Table 2. Incidence of infected whole tubers in soil and incidence of sporulation on tuber disks when soil surface was treated with fungicide or water and then infested with spores of Phytophthora infestans 1,3 , or 7 days after fungicide application (experiment $\mathrm{C})^{\mathrm{W}}$

\begin{tabular}{|c|c|c|c|c|c|c|}
\hline \multirow[b]{2}{*}{ Treatment } & \multicolumn{3}{|c|}{$\begin{array}{l}\text { Mean \% incidence of } \\
\text { infected whole tubers }\end{array}$} & \multicolumn{3}{|c|}{$\begin{array}{c}\text { Mean \% incidence of } \\
\text { sporulation on tuber disks }\end{array}$} \\
\hline & 1 & 3 & 7 (days) & 1 & 3 & 7 (days) \\
\hline Mancozeb & $0 \mathrm{a}^{\mathrm{z}}$ & $0 \mathrm{a}$ & $65 \mathrm{a}$ & $0 \mathrm{a}$ & $0 \mathrm{a}$ & $83 \mathrm{a}$ \\
\hline Metiram & $0 \mathrm{a}$ & $17 \mathrm{a}$ & $78 \mathrm{a}$ & $0 \mathrm{a}$ & $0 \mathrm{a}$ & $67 \mathrm{a}$ \\
\hline Water & $58 \mathrm{~b}$ & $83 \mathrm{~b}$ & $100 \mathrm{a}$ & $100 \mathrm{~b}$ & $100 \mathrm{~b}$ & $100 \mathrm{a}$ \\
\hline
\end{tabular}

${ }^{w}$ Fungicides and water controls were arranged in a completely randomized design with three replicates. Each pot contained six whole cv. Ranger Russet tubers buried $1 \mathrm{~cm}$ in a Quincy medium sand in pots under field conditions. Soil was infested with $10^{6}$ sporangia/pot in $100 \mathrm{ml}$ water that had been chilled for $2 \mathrm{~h}$ at $4^{\circ} \mathrm{C}$ to induce zoospore formation. Water was applied at $800 \mathrm{ml}$ to the soil in each pot after application of inoculum and every $48 \mathrm{~h}$ after the initial irrigation until day seven. Tuber disks were inoculated with infested soil $24 \mathrm{~h}$ after soil infestation and $48 \mathrm{~h}$ after application of fungicides or water to the soil. Mancozeb (Penncozeb 75 DF) and metiram (Polyram 80 DF) were applied at 1.68 and $1.79 \mathrm{~kg} / \mathrm{ha}$, respectively, at a rate of 281 liters of water per hectare.

x Whole tubers assayed for infection 14 days after application of inoculum to soil.

y Two $1 \mathrm{~cm}^{3}$ soil plugs per pot were placed on separate tuber disks of cv. Ranger Russet and incubated at $15^{\circ} \mathrm{C}$ for 6 days.

${ }^{\mathrm{z}}$ Different letters represent significant differences between treatments for a given day determined using a series of pair-wise differences by tests of two proportions with an adjusted Bonferroni procedure $(P=0.001)$

Table 3. Incidence of sporulation on potato tuber disks when the soil surface was treated with water or mancozeb and then infested with spores of Phytophthora infestans 3 to 7 days after fungicide or water application (experiment D) ${ }^{\mathrm{x}}$

\begin{tabular}{|c|c|c|c|c|}
\hline \multirow[b]{3}{*}{ Day } & \multicolumn{4}{|c|}{ Mean \% incidence of sporulation on tuber disks ${ }^{y}$} \\
\hline & \multicolumn{2}{|c|}{ Trial 1} & \multicolumn{2}{|c|}{ Trial 2} \\
\hline & Water $^{\mathbf{z}}$ & Mancozeb & Water & Mancozeb \\
\hline 3 & 100 & 0 & 75 & 0 \\
\hline 4 & 100 & 0 & 75 & 0 \\
\hline 5 & 100 & 0 & 72 & 0 \\
\hline 6 & 100 & 33 & 72 & 7 \\
\hline 7 & 100 & 67 & 73 & 12 \\
\hline
\end{tabular}

${ }^{\mathrm{x}}$ Fungicides and water controls were arranged in a completely randomized design with four replicates. Quincy medium sand contained in pots under field conditions was infested with $10^{6}$ sporangia/pot in $100 \mathrm{ml}$ water that had been chilled for $2 \mathrm{~h}$ at $4^{\circ} \mathrm{C}$ to induce zoospore formation. Water was applied at $800 \mathrm{ml}$ to the soil in each pot after the application of inoculum to the soil and every $48 \mathrm{~h}$ after the initial irrigation until day seven. Tuber disks were inoculated with infested soil $24 \mathrm{~h}$ after soil infestation and $48 \mathrm{~h}$ after application of mancozeb (Penncozeb $75 \mathrm{DF}$ ) or water to the soil. Mancozeb was applied at $1.68 \mathrm{~kg} / \mathrm{ha}$ at a rate of 281 liters of water per hectare.

y Two $1 \mathrm{~cm}^{3}$ soil plugs per pot were placed on separate tuber disks of cv. Ranger Russet and incubated at $15^{\circ} \mathrm{C}$ for 6 days.

${ }^{\mathrm{z}}$ Water was significantly different from mancozeb for each day for both trials 1 and 2 determined using a series of pair-wise differences by tests of two proportions with an adjusted Bonferroni procedure $(P<0.0001$ to $P<0.02)$. 
EBDC fungicides are applied at 5-day intervals. Mancozeb and metiram are relatively inexpensive fungicides, and no known resistance has developed to them in the field during their use on potatoes.

Metiram + triphenyltin hydroxide and metiram + zoxamide also were effective in preventing whole tuber infection, but the protection was most likely due to the metiram component alone. These fungicides also would protect tubers during the growing season when soil is not directly exposed if adequate amounts were redistributed from foliage to the soil surface.

Tubers are sometimes harvested during wet weather, which favors tuber infection (8). Spore survival in wet soil is longer than the average 2 -week period growers wait between vine kill and harvest $(17,20,23)$. Application of an EBDC product to the soil shortly before harvest may reduce the number of surviving spores on the soil surface and decrease the likelihood of tuber infection.

The Quincy medium sand used as the soil medium in this study is one of the most porous soil types found in the Columbia Basin (19), and pore sizes are large enough to allow the movement of both sporangia (6) and zoospores (1) of $P$. infestans. The soil was not completely water saturated before application of inoculum to allow for rapid movement of spores through the soil once the inoculum was added (26), but tuber infection was still prevented in this study when EBDC fungicides were applied to soil. To summarize, the EBDC fungicides were effective in preventing whole tuber infection even when soil conditions were conducive for rapid movement of spores to tubers buried only 1 to $2 \mathrm{~cm}$ below the soil surface.

Cyazofamid was the only non-EBDC fungicide with fungicidal activity on or in soil based on the tuber disk method of assessment. Whole tubers were also protected when cyazofamid was applied to soil, but the duration of protection was not determined. Cyazofamid cannot be applied within 7 days of harvest due to label restrictions.

Fluazinam and fenamidone provided protection to whole tubers but were not fungicidal to spores based on the tuber disk method of assessing spore viability (Table 1). These products may interfere with other processes associated with whole tuber infection. They may induce defense mechanism within the tubers or interfere with the movement and capabilities of zoospores to locate infection sites such as eyes. Fluazinam possesses many properties such as a long half-life and poor soil mobility (27) that are ideal characteristics of a soil-applied protectant fungicide to provide relatively long lasting protection to tubers in soil. Further research is needed to understand why whole tuber infection was significantly reduced but germination of spores on tuber disks was not. Both meth- ods of determining spore viability may determine different modes of action of the fungicides that inhibit infection.

Soil-applied copper and triphenyltin hydroxide were expected to provide protection against tuber infection, but both fungicides were ineffective in the present study. Copper fungicides are available to organic potato growers for late blight management. Appropriate recommendations to organic growers based on the present research would be to not apply copper to the soil to protect tubers from infection, and only to apply it to protect potato foliage. The inability of copper and triphenyltin hydroxide to adversely affect spores in the soil may be due to complexes that are formed when they are incorporated. Copper and triphenyltin hydroxide may also kill microorganisms in the soil that would adversely affect spores of $P$. infestans. Possible reasons for the differences between effectiveness of copper and triphenyltin hydroxide on potato foliage compared to copper in the soil need to be investigated.

The fungicides tested in this study represent materials used most frequently by conventional and organic potato growers to manage late blight on foliage and include old and new protective chemistries. Metalaxyl was not tested because it is no longer in use in the Columbia Basin of Washington due to the development of resistant isolates (10).

Continuing timely fungicide applications until harvest is a management key tactic in reducing late blight tuber rot in the Columbia Basin (15). Due to this research, fungicides or fungicide mixtures containing mancozeb or metiram are currently encouraged to be incorporated into the fungicide programs for late blight control from mid-tuber bulking to harvest in the Columbia Basin, especially when foliar infections by $P$. infestans have been identified in the field or adjacent fields.

\section{ACKNOWLEDGMENTS}

Funding for this study was provided by the Washington State Potato Commission. We thank Zahi Kanaan-Atallah and Gary Grove for critically reading the manuscript.

\section{LITERATURE CITED}

1. Barr, D. J. S., and Desaulniers, N. L. 1990. The flagellar apparatus in the Phytophthora infestans zoospore. Can. J. Bot. 68:2112-2118.

2. Crosier, W. 1934. Studies in the biology of Phytophthora infestans (Mont.) de Bary. Pages 1-40 in: Memoir 155. Cornell University, Agricultural Experiment Station, Ithaca, NY.

3. Dubey, T., James, R. V., and Stevenson, W. R. 1997. Effect of fungicide on viability of Phytophthora infestans sporangia in soil. (Abstr.) Phytopathology 87:S26.

4. Dubey, T., James, R. V., and Stevenson, W. R. 1998. The effect of 15 fungicides on viability of Phytophthora infestans sporangia in soil. (Abstr.) Phytopathology 88:S23.

5. Dubey, T., James, R. V., and Stevenson, W. R. 1999. The effect of fungicides on germination of Phytophthora infestans zoospores in soil. (Abstr.) Phytopathology 89:S21-S22.

6. Erwin, D. C., and Ribeiro, O. K. 1996. Phytophthora Diseases Worldwide. American Phy- topathological Society, St. Paul, MN.

7. Fehrmann, H. 1963. Untersuchungen Zur Pathogenese Der Durch Phytophthora infestans Hervorgerufenen Braunfaule Der Kartoffelknolle. Phytopathol. Z. 46:371-376.

8. Fry, W. E., Thurston, H. D., and Stevenson, W. R. 2001. Late blight. Pages 28-30 in: Compendium of Potato Diseases. 2nd ed. W. R. Stevenson, R. Loria, G. D. Franc, and D. P. Weingartner, eds. American Phytopathological Society, St. Paul, MN.

9. Goodwin, S. B., Smart, C. D., Sandrock, R. W., Deahl, K. L., Punja, Z. K., and Fry, W. E. 1998. Genetic change within populations of Phytophthora infestans in the United States and Canada 1994 to 1996: Role of migration and recombination. Phytopathology 88:939-949.

10. Hamm, P. B., Fry, B. A., and Jaeger, J. 1994 Occurrence and frequency of metalaxyl insensitivity and mating types of Phytophthora infestans in the Columbia Basin of Oregon and Washington. (Abstr.) Phytopathology 84:1123.

11. Hosmer, D. W., and Lemeshow, S. 2000. Applied Logistic Regression. John Wiley \& Sons, New York.

12. Jensen, J. L. 1887. Moyens de combattre et de detruire le Peronospora de la pomme de terre. Mem. Soc. Nat. Agric. Fr. 131:31-156.

13. Johnson, D. A., Cummings, T. F., and Hamm, P. B. 2000. Cost of fungicides used to manage potato late blight in the Columbia Basin: 1996 to 1998. Plant Dis. 84:399-402.

14. Johnson, D. A., Cummings, T. F., Hamm, P. B., Rowe, R. C., Miller, J. S., Thornton, R. E., Pelter, G. Q., and Sorensen, E. J. 1997. Potato late blight in the Columbia Basin: An economic analysis of the 1995 epidemic. Plant Dis. 81:103-106.

15. Johnson, D. A., Martin, M., and Cummings, T. F. 2003. Effect of chemical defoliation, irrigation water, and distance from the pivot on late blight tuber rot in center-pivot irrigated potatoes in the Columbia Basin. Plant Dis. 87:977-982.

16. Kuehl, R. O. 2000. Design Experiments: Statistical Principles of Research Design and Analysis. Duxbury Thomson Learning, New York.

17. Lacey, J. 1965. The infectivity of soils containing Phytophthora infestans. Ann. Appl. Biol. 56:363-380.

18. Lacey, J. 1967. The role of water in the spread of Phytophthora infestans in the potato crop. Ann. Appl. Biol. 59:245-255.

19. Lenfesty, C. D. 1967. Soil survey of Adams county, Washington. U.S. Dep. Agric., Soil Conservation Serv., Washington, DC.

20. Murphy, P. A. 1922. The bionomics of the conidia of Phytophthora infestans. Sci. Proc. R. Dublin Soc. 16:442-466.

21. Murphy, P. A., and Mckay, R. 1925. Further experiments on the sources and development of blight infection in potato tubers. J. Dep. Lds Agric., Dubl. 25:10-21.

22. Porter, L. D., Dasgupta, N., and Johnson, D. A. 2005. Effects of tuber depth and soil moisture on infection of potato tubers in soil by Phytophthora infestans. Plant Dis. 89:146-152.

23. Porter, L. D., and Johnson, D. A. 2004. Survival of Phytophthora infestans in surface water. Phytopathology 94:380-387.

24. Ryan, T. P. 1996. Modern Regression Methods. John Wiley \& Sons, New York.

25. Sato, N. 1979. Effect of soil temperature on the field infection of potato tubers by Phytophthora infestans. Phytopathology 69:989-993.

26. Scott, H. D. 2000. Soil Physics: Agricultural and Environmental Applications. Iowa State University Press, Ames.

27. U.S. Environmental Protection Agency, Office of Prevention, Pesticides and Toxic Substance. August 10, 2001. Pesticide Fact Sheet for Fluazinam. Online publication.

28. Zan, K. 1962. Activity of Phythophthora infestans in soil in relation to tuber infection. Trans. Br. Mycol. Soc. 45:205-221. 